\title{
KESEJAHTERAAN KARYAWAN PERSPEKTIF MAQASHID SYARIAH PADA PUSAT PENELITIAN KOPI DAN KAKAO1)
}

\author{
Rohma Vihana Enggardini \\ Mahasiswa Program Studi S1 Ekonomi Islam-Fakultas Ekonomi dan Bisnis-Universitas Airlangga \\ Email : dininuswantoro@gmail.com \\ Moh. Qudsi Fauzy \\ Departemen Ekonomi Syariah-Fakultas Ekonomi dan Bisnis-Unversitas Airlangga \\ Email : qudsifauzy1@gmail.com
}

\begin{abstract}
:
The purpose of this study is to determine the economic impact in improving the welfare of employees Coffee and Cocoa Research Center Indonesia when viewed through the perspective of maqashid sharia. The method used is a qualitative approach, a strategy case studies and descriptive analysis techniques are collecting data through interviews and observations of informants. Informants are employees working at the Coffee and Cocoa Research Center Indonesia amounting to nine people. The Results from this study is economic impact and fulfillment of welfare for employees at the Coffee and Cocoa Research Center still ranks necessities. Five indicators used in this study is maqashid syariah can be met by almost all employees. The economic impact can be seen, among others, the changes experienced by the employee, the changes are seen from the increased monthly income, expenditure control, insufficient subsistence, and increasing assets and preparation for future family prepared before retirement arrives.
\end{abstract}

Keywords: Employee Welfare, Maqashid Sharia

\section{PENDAHULUAN}

\section{Latar Belakang}

Perusahaan dan karyawan pada hakekatnya saling membutuhkan, karyawan adalah asset perusahaan karena tanpa adanya sumber daya manusia maka perusahaan tidak akan bisa berjalan, begitu juga karyawan tidak dapat menunjang kesejahteraan hidupnya tanpa adanya perusahaan sebagai tempat mencari nafkah sekaligus implementasi dari disiplin ilmu yang mereka miliki sendiri. Maka karyawan harus diperhatikan kesejahteraannya, jangan hanya dituntut kewajibannya saja dengan berbagai macam beban pekerjaan, begitu pula dengan karyawan yang jangan hanya menuntut hak mereka tetapi pekerjaan dan tanggung jawab sebagai karyawan tidak diselesaikan. Namun masih ada perusahaan yang kurang memperhatikan karyawannya sehingga karyawan menjadi kehilangan motivasi, malas, dan terkesan tidak baik hasil pekerjaannya.

$$
\text { Untuk mencegah terjadinya }
$$
tindakan karyawan yang tidak diinginkan oleh perusahaan atau instansi, maka tugas manajemen perusahaan yang harus memenuhi tuntutan karyawan dengan memberikan kesejahteraan yang adil dan bijaksana, semua itu dilakukan demi terciptanya kesejahteraan karyawan dan kesejahteraan perusahaan.

Pentingnya kesejahteraan karyawan adalah untuk mempertahankan

1) Jurnal ini merupakan bagian dari skripsi dari Rohma Vihana E, NIM: 041114124, yang diuji pada tanggal 10 Agustus 2016 
karyawan agar tidak pindah ke perusahaan lain, meningkatkan motivasi dan semangat kerja, dan meningkatkan sikap loyalitas karyawan terhadap perusahaan untuk mempertahankan karyawan ini hendaknya diberikan kesejahteraan/kompensasi lengkap. Kesejahteraan yang diberikan sangat berarti dan bermanfaat untuk memenuhi kebutuhan fisik dan mental karyawan beserta keluarganya. Usaha yang dilakukan untuk mempertahankan dan memperbaiki kondisi fisik dan mental karyawan agar semangat kerja meningkat adalah melalui peningkatan kesejahteraan karyawan yang disusun berdasarkan peraturan legal, berasaskan keadilan dan kelayakan serta berpedoman kepada kemampuan perusahaan.

Karyawan adalah modal utama bagi setiap perusahaan, sebagai modal, karyawan perlu dikelola agar tetap produktif. Akan tetapi pengelolaan karyawan bukanlah hal yang mudah, karena mereka mempunyai pikiran, perasaan, status, keinginan dan latar belakang yang heterogen. Oleh sebab itu perusahaan harus bisa mendorong mereka agar tetap produktif dalam mengerjakan tugas-tugas dan tanggung jawabnya masing-masing yaitu dengan memberikan sesuatu yang menimbulkan kepuasan dalam diri karyawan, sehingga perusahaan dapat mempertahankan karyawan yang loyalitas dan dedikasi yang tinggi serta memiliki pengalaman dan potensi dalam bidang pekerjaannya.
Karyawan semacam itu merupakan asset utama yang penting dan salah satu factor penunjang keberhasilan pekerjaan dalam menjalankan perusahaan.

Kesejahteraan adalah balas jasa lengkap (materi dan non materi yang diberikan oleh pihak perusahaan berdasarkan kebijaksanaan. Tujuannya untuk mempertahankan dan memperbaiki kondisi fisik dan mental karyawan agar produktifitasnya meningkat (Hasibuan, 2003:183).

Kesejahteraan dapat dipandang sebagai uang bantuan lebih lanjut kepada karyawan. Terutama pembayarannya kepada mereka yang sakit, uang bantuan untuk tabungan karyawan, pembagian berupa saham, asuransi, perawatan dirumah sakit, dan pensiun (Hasibuan, 2003:185)

Pentingnya

program

kesejahteraan yang diberikan kepada karyawan dalam rangka meningkatkan disiplin kerja karyawan yang dikemukakan oleh Hasibuan (2003:182) "Pemberian kesejahteraan akan menciptakan ketenangan, semangat kerja, dedikasi, disiplin dan sikap loyal terhadap perusahaan sehinggalabour turnover relative rendah."

Dengan tingkat kesejahteraan yang cukup, maka mereka akan lebih tenang dalam melaksanakan tugastugasnya. Dengan peningkatan kesejahteraan tersebut diharapkan para karyawan akan lebih berdisiplin dan dapat bekerja dengan baik. Contohnya saja karyawan Rumah Sakit Marzoeki Mahdi pada Hari Senin, 10 Maret 2014, mereka menggelar unjukrasa di lapangan rumah sakit jiwa itu di Jl. Dr Semeru, Kecamatan Bogor Barat menuntut 
peningkatan kesejahteraan. Sejak enam tahun terakhir pendapatan rumah sakit mengalami kenaikan siginifikan. Namun, kesejahteraan karyawan tidak ada peningkatan, dengan pembagian 60 persen untuk operasional dan 40 persen untuk tunjangan kesejahteraan para karyawan. Dirasa belum cukup untuk memenuhi kesejahteraan karyawan rumah sakit tersebut.

Sebagai salah satu pelopor pengembangan ilmu pengetahuan dan teknologi pertanian yang juga bergerak di bidang jasa, persoalan kesejahteraan karyawan di Pusat Penelitian Kopi dan Kakao menjadi hal yang layak untuk di ketahui dan diteliti, serta membutuhkan suatu pengelolaan yang baik mengingat selama ini pemenuhan kesejahateraan karyawan perusahaan/instansi lain masih jauh dari harapan. Serta dapat dilihat pula bagaimana dampak ekonomi yang ada pada karyawan dengan bekerja di Pusat Penelitian Kopi dan Kakao. Peningkatan perekonomian karyawan dapat dilihat dari bagaimana pendapatan perbulan, pengaturan pengeluaran, pemenuhan atau kecukupan kebutuhan hidup, aset yang dimiliki dan persiapan masa depan keluarga.

Sedangkan Islam sebagai agama universal yang juga menyangkut persoalan pemenuhan kesejahteraan, telah banyak memberikan aturan sejak zama Rasulullah sebagai pemimpin. Tujuan manusia pada hakikatnya tidak hanya sampai pemenuhan kesejahteraan dalam duniawi saja. Seorang muslim yang memiliki keimanan dan mempercayai ada kehidupan setelah kematian, tentu saja mempersiapkan kebutuhannya diakhirat kelak, agar menggapai kemaslahatan yang bersifat baqa'. Sebelum dapat mencapai hal tersebut, maka manusia harus dapat memenuhi dan menjaga lima hal utama yang tidak dapat ditinggalkan oleh manusia, yaitu agama, jiwa, akal, keturunan, dan harta.

Kemampuan memenuhi kebutuhan hak-hak dasar tersebut tercermin dalam maqashid syariah (objektivitas syariah). Maqashid syariah merupakan jalan untuk memenuhi tiga tahapan kebutuhan manusia, yakni (1) Dharuriyyah, (2) Hajiyyah, (3) Tahsiniyyah. Istilah maqashid syariah dipopulerkan oleh Asy-Syatibi yang tertuang dalam karyanya Muwaffaqat sebagaimana dalam ungkapan Bakri (1994:91): "Inna haadzihizyyari'atu wu dli'at litachqiai maqosidissyaari'i qiyaami mashoolichifiddiini waddunyaa ma'an"

Artinya :"sesungguhnya syariat ini (diciptakan) untuk meneguhkan tujuantujuan syariat (itu sendiri) untuk menegakkan kemaslahatan didalam agama dan dunia secara bersama sama".

Surat QS. Al-Jatsiyah: 18

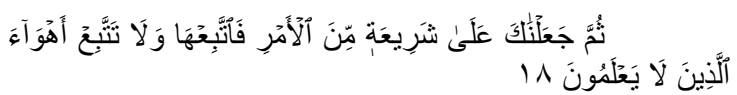

Artinya: "Kemudian Kami jadikan kamu berada di atas suatu syariat (peraturan) dari urusan (agama itu), Maka ikutilah syariat itu dan janganlah kamu ikuti hawa nafsu orang-orang yang tidak mengetahui".

Dalam setiap ekonominya, manusia baik secara individu maupun 
kelompok harus diarahkan pada pencapaian tujuan falah. Kesejahteraan dalam Islam tersebut tidak hanya menyangkut kehidupan dunia (materi), akan tetapi menyangkut dunia akhirat yang antara keduanya saling terikat. Sehingga untuk membentuk sumber daya insani yang dapat meraih kedua tujuan tersebut, pencapaian falah dapat terwujud apabila terpenuhi kebutuhankebutuhan hidup manusia secara seimbang. Tercukupinya kebutuhan masyarakat akan memberi dampak yang disebut maslahah.

Setiap pemimpin selayaknya mengimplementasikan kebijakan dengan memperhatikan hak-hak yang menjadi dasar kebutuhan yang pekerjanya. Hal ini tertuang dalam maqashid syariah yang merupakan satu kesatuan tujuan umum syariat Islam, yang intinya adalah bagaimana Islam sebagai pandangan hidup yang seimbang dan terpadu, didesain untuk mengantarkan kebahagian manusia (falah), sehingga melalui pencapaian inilah seorang pemimpin dapat menjaga penegakkan keharmonisan antara kebutuhankebutuhan moral dan material karyawan serta aktualisasi keadilan sosio-ekonomi dan persaudaraan dalam setiap aktifitasnya.

Untuk meningkatkan eksistensinya dalam perkembangan ilmu pengetahuan dan teknologi pertanian di Indonesia khususnya untuk komoditi kopi dan kakao pada khususnya, strategi dan kebijakan menuju peningkatkan kesejahteraan karyawan dan peneliti sebagai tenaga ahli dan pengabdi masyarakat diharapkan mampu memberikan inovasi terbaru yang lebih unggul.

\section{LANDASAN TEORI}

Dampak merupakan sebuah konsep pengawasan internal sangat penting, yang dengan mudah dapat diubah menjadi sesuatu yang dipahami dan ditanggapi secara serius oleh manajemen. Dampak menurut Waralah Rd Christo., (2008) adalah sesuatu yang diakibatkan oleh sesuatu yang dilakukan, bisa positif atau negatif atau pengaruh kuat yg mendatangkan akibat (baik negatif maupun positif).

Pandangan dunia mengenai kesejahteraan, dimana setiap manusia bertujuan mencapai kesejahteraan dalam hidupnya, namun kesejahteraan menurut berbagai versi individu berbeda-beda sudut pandangnya. Namun secara umum terdapat persamaan dalam pengertian kesejahteraan tersebut yakni hanya memaknai dari beberapa sisi saja, dengan mengabaikan dan hanya menggunakan aspek spiritual sebagai pelengkap.

Indikator yang sering dipakai untuk melihat kesejahteraan adalah GNP per kapita atau PDB per kapita atau produktivitas per kapita. Menurut Miles dan Irvings (1985:4), terdapat empat indikator yang digunakan untuk mengetahui kesejahteraan suatu keluarga, yaitu :

1) Rasa aman (security) dilihat dari kerentanan terhadap kematian yang dicerminkan oleh angka harapan 
hidup dan kerentanan terhadap kemiskinan.

2) Kebebasan (freedom), diukur dengan indikator sejauh mana memiliki akses terhadap sumber daya, misal : pemilikan kapital, mobilitas pekerjaan serta pemilikan waktu luang.

3) Kesejahteraan (welfare), dalam arti sempit karena di dalamnya terkandung variabel kesehatan fisik dan pemilikan barang komiditi.

4) Jati diri (identity), diukur melalui indikator yaitu: insiden bunuh diri, kecanduan pada obat penenang, dan insiden gangguan jiwa.

Ajaran Islam telah menjelaskan bahwa sesungguhnya tujuan dasar Islam adalah terwujudnya kesejahteraan baik di dunia maupun akhirat, sehingga tidak sebatas aspek material (fisik) saja namun lebih menekankan aspek religius dalam hidup. Kesejahteraan dalam Islam berpedoman pada Al-Qur'an dalam surat Al Mu'minun ayat 1:

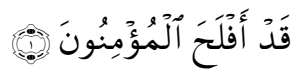

"Qad aflahal-mu'minūn"

Artinya: "Sesungguhnya beruntunglah orang-orang yang beriman," (Departemen Agama Republik Indonesia, 2007:689)

Menurut Shihab (2002:313) dalam tafsirnya beruntung yang dimaksud adalah tercapainya kebahagiaan. Kebahagiaan ada dua, yakni dunia dan akhirat. Kebahagiaan dunia menurut ar Raghib al-Ashfahani adalah memperoleh hal yang menjadikan hidup nyaman di dunia antara lain berupa kelanggengan kekayaan dan kemuliaan.
Indikator sejahtera menurut Islam adalah terpenuhinya kebutuhan fisik dari rizqi yang halal, hidup sehat baik jasmani maupun rohani, keberkahan rezeki yang diterima, keluarga yang sakinah mawaddah wa rahma, rasa cinta kasih sesama, ridha dan qanaa'ah dengan apa yang diberikan Allah kepadanya serta merasa bahagia. Dengan demikian maka kesejahteraan bukan hanya diukur dari terpenuhinya kebutuhan fisik dan materi saja, melainkan juga terpenuhinya kebutuhan spritual.

Karyawan merupakan kekayaan utama dalam suatu perusahaan, karena tanpa adanya keikutsertaan mereka, aktifitas perusahaan tidak akan terlaksana. Karyawan merupakan aset perusahaan yang harus dilindungi dan diperhatikan hak nya berupa pemenuhan kebutuhan dan kesejahteraan. Karyawan adalah orang yang bekerja pada suatu lembaga (kantor, perusahaan, dan sebagainya) dengan mendapat gaji (upah); pegawai; pekerja.

Secara etimologi maqashid syariah terdiri dari dua kata yakni maqashid dan al-syariah. Maqashid bentuk jamak dari maqshid yang berarti tujuan atau kesengajaan. Al-syariah diartikan sebagai bahasa jalan menuju sumber air atau dapat pula dikatakan sebagai jalan ke arah sumber pokok kehidupan yang berarti maksud atau tujuan disyariatkan hukum dalam Islam. Kemudian dalam upaya mewujudkan dan memelihara kelima unsur pokok dalam dasar maqashid syariah al-Syatibi membagi 
kepada tiga tingkatan, yaitu kebutuhan dharuriyat, kebutuhan hajiyat, dan kebutuhan tahsiniyat. (Wibowo, 2012)

1. Tujuan Primer (al-Daruriyyat)

Tujuan primer hukum Islam adalah tujuan hukum yang mesti ada dari adanya kehidupan manusia. Apabila tujuan itu tidak tercapai, maka akan menimbulkan ketidakajegan kemaslahatan hidup manusia di dunia dan akhirat, bahkan merusak kehidupan itu sendiri. (Praja Juhaiya:1995:101)

Kesempurnaan atas perlindungan terhadap manusia dapat dijelaskan pada masing-masing tujuan primer hukum Islam yang biasa disebut "maqasid alsyariah". Menurut Imam Al-Ghazali, "tujuan utama syariah adalah mendorong kesejahteraan manusia yang terletak dalam perlindungan terhadap agama, jiwa, akal, keturunan, dan harta benda. Apa saja yang menjamin terlindunginya lima perkara ini berarti melindungi kepentingan umum dan dikehendaki".

\section{2). Tujuan sekunder (al-Hajiyyat)}

Tujuan sekunder hukum Islam ialah terpilihnya tujuan kehidupan manusia yang terdiri atas berbagai kebutuhan sekunder hidup manusia itu. Kebutuhan sekunder ini bila tidak terpenuhi, tidak akan mengakibatkan kerusakan yang menimbulkan kerusakan hidup manusia secara umum.

3). Tujuan Tersier (at-Tahsiniyyat)

Tujuan tersier hukum ialah tujuan hukum yang digunakan untuk menyempurnakan hidup manusia. Pencapaian teresier hukum Islam ini biasannya terdapat dalam bentuk budi pekerti yang mulai akhlaq alkarimah.

Memelihara agama (Hifdzud Din)

Memelihara agama merupakan tujuan utama hukum Islam, karena agama merupakan pedoman hidup manusia. Di dalam agama terkandung unsur akidah bagi setiap muslim. Selain itu terdapat unsur syariah yang merupakan jalan hidup seorang muslim dalam hubungannya dengan Tuhan-Nya, maupun dengan sesama manusia (Duhriah, 2015)

Memelihara Jiwa (Hifdzun Nafs)

Allah SWT mensyariatkan agar mewujudkan dan melestarikan ras manusia dengan jalan pernikahan dan melanjutkan keturunan. Oleh sebab itu Islam mewajibkan secara pasti untuk makan, minum, pakaian dan lain-lainnya dalam rangka menjamin kehidupan manusia. (Duhriah, 2015)

Memelihara Akal (Hifdzul Aql)

Allah SWT melarang segala sesuatu yang dapat merusak atau melemahkan akal. Allah SWT mensyariatkan untuk menjaganya dan menganjurkan untuk memanfaatkan akal dalam mendapatkan ilmu. Pemeliharaan akal sangat penting karena dengan akalnya manusia dapat berfikir tentang Allah SWT, alam semesta dan dirinya. Adapun hal yang perlu dilakukan orang Islam dalam mencerdaskan akalnya ialah melalui pendidikan. (Duhriah, 2015)

Memelihara Kehormatan dan Keturunan (Hifdzun Nasl)

Memelihara keturunan adalah memelihara jenis kemanusiaan dan 
menumbuhkan kasih sayang serta saling mencintai diantara manusia. Orang tua dituntut menanamkan keyakinan, ibadah, dan akhlak agar anak selalu terpelihara dengan baik. (Duhriah, 2015).

Memelihara Harta (Hifdzul Maal)

Memelihara harta dapat dilakukan dengan cara antisipasi terhadap perbuatan yang melanggar aturan seperti mencuri, berjudi, menyogok, dan lainlainnya. (Duhriah, 2015).

\section{METODOLOGI PENELITIAN}

Pendekatan yang digunakan dalam penelitian ini adalah pendekatan kualitatif. Spradley mengungkapkan bahwa pendekatan kualitatif adalah suatu proses penelitian dan pemahaman yang berdasarkan pada metodologi yang menyelidiki suatu fenomena, budaya sosial dan masalah manusia. Pada pendekatan kualitatif (Cresswell, 1998:15), peneliti membuat suatu gambaran kompleks, meneliti katakata, laporan terinci dari pandangan informan dan melakukan studi pada situasi yang alami.

\section{Ruang Lingkup Penelitian}

Penelitian yang dimaksud adalah dalam rangka untuk menjawab rumusan masalah yaitu bagaimana dampak ekonomi Pusat Penelitian Kopi dan Kakao Indonesia dalam meningkatkan kesejahteraan karyawan apabila ditinjau melalui perspektif maqashid syariah. Rumusan masalah tersebut menjadi acuan dalam penelitian ini. Ruang lingkup penelitian ini terbatas pada bagaimanakah penerapan kebijakan yang digunakan sebagai upaya peningkatkan kesejahteraan karyawan di Pusat Penelitian Kopi dan Kakao Indonesia, sebagai ukuran kesejahteraan maka dapat dilihat melalui lima indikator maqashid syariah, yang terdiri atas: agama, jiwa, akal, keturunan, harta. Kelima indikator tersebut semuanya dipergunakan dalam penelitian ini berdasarkan peringkat dharuriyyat, hajiyyat dan tahsiniyyat. Walaupun pada dasarnya kelima aspek tersebut adalah dasar untuk mencapaifalah yaitu kebahagiaan dunia dan akhirat, namun dalam penelitian ini tidak sampai meneliti sampai pada pencapaian falah tersebut, melainkan hanya sampai pada perspektif maqashid syariah saja.

Penelitian ini dilakukan pada pimpinan Pusat Penelitian Kopi dan Kakao Indonesia yaitu Kepala Biro Umum dan SDM dan Kepala urusan pengembangan kepegawaian dan SDM yang kemudian akan dilakukan cross check pada karyawan yang berjumlah 9 orang.

\section{Lingkup pertanyaan pada penelitian ini adalah :}

a. Agama meliputi kelengkapan sholat, pengajian dan pembayaran zakat.

b. Jiwa meliputi asuransi kesehatan dan kebutuhan makan.

c. Akal meliputi pengembangan keilmuan, pelatihan serta beasiswa.

d. Keturunan meliputi cuti hamil dan melahirkan, fasilitas persalinan, asuransi untuk anak dan pembatasan usia nikah bagi karyawan. 
e. Sedangkan harta meliputi honor dan tunjangan.

\section{Jenis dan Sumber Data}

Data yang dibutuhkan ada dua jenis, yaitu primer (utama) dan sekunder (tambahan/penunjang). Data primer berasal dari hasil observasi dan wawancara di lapangan, sedangkan data sekunder yang diperoleh dari suatu objek penelitian yang berupa arsip, laporan-laporan masa lalu dan dokumendokumen yang relevan serta kajian pustaka yang berkaitan dengan permasalahan. Sedangkan sumber dan jenis data dalam penelitian ini diperoleh dari:

a. KeyInforman

b. Data sekunder

\section{Teknik Pengumpulan Informan}

Penelitian ini menggunakan teknik purposive dan random sampling. Menurut Sugiyono (2013:218) purposive sampling adalah teknik pengambilan sampel sumber data dengan pertimbangan tertentu. Dalam penelitian ini diambil informan utama diantaranya karyawan tetap yang bekerja di Pusat Penelitian Kopi dan Kakao. Untuk memperoleh informan ditetapkan beberapa kriteria yang penerapannya bersifat purposive sampling dan random sampling dalam penelitian ini informan yang akan diteliti adalah diantaranya sebagai berikut :

1. Karyawan tetap yang bekerja di Pusat Penelitian Kopi dan Kakao.

2. Karyawan yang telah bekerja lebih dari 5 tahun.

\section{Teknik Pengumpulan Data}

Penulis mengamati langsung di lapangan tentang:

a. Kondisi fisik dan non Pusat Penelitian Kopi dan Kakao

b. Program-program dalam peningkatan kesejahteraan karyawan

c. Implementasi kebijakan pimpinan dalam melaksanakan programprogram tersebut.

Peneliti memiliki peran serta dalam mengumpulkan data dengan cara pengarahan batas studi merekam dan mencatat data. Peneliti juga melakukan wawancara yang mendalam secara terbuka pada karyawan Pusat Penelitian Kopi dan Kakao. Hal ini akan dilakukan kurang lebih 2 Minggu dengan jumlah informan 9 orang.

Data sekunder diperoleh dengan prosedur sebagai berikut:

Studi pustaka dilakukan dengan cara mengumpulkan dan mempelajari literatur-literatur yang berkaitan dengan penelitian untuk dijadikan sebagai landasan teori sebagai acuan penelitian. Berbagai macam literatur yang digunakan diperoleh dengan berbagai cara seperti mengunjungi perpustakaan kampus B Universitas Airlangga dan ruang baca Fakultas Ekonomi dan Bisnis Universitas Airlangga Surabaya serta mengunjungi perpusatakaan Pusat Penelitian Kopi dan Kakao.

Saat pengumpulan data peneliti mendapatkan data dari hasil observasi langsung dan wawancara yang mendalam dari anggota yang menjadi 
obyek penelitian yakni dua orang pimpinan dan cross check dengan karyawan di beberapa Divisi yang sudah ditentukan.

\section{HASIL DAN PEMBAHASAN}

\section{Dampak Ekonomi}

Dampak ekonomi yang dapat dilihat dari penelitian ini antara lain perubahan yang dialami oleh karyawan yang bekerja pada Pusat Penelitian Kopi dan Kakao Indonesia, perubahan tersebut dapat dilihat melalui pendapatan perbulan, pengaturan pengeluaran, pemenuhan atau kecukupan kebutuhan hidup, aset yang dimiliki dan persiapan masa depan keluarga.

Dilihat dari pendapatan perbulan yang diterima oleh karyawan, rata-rata karyawan menerima 5-11 juta perbulan, sedangkan karyawan golongan bawah menerima 2-3 juta perbulan. Dengan pendapatan yang sekian, seluruh karyawan menyatakan cukup untuk memenuhi kebutuhan hidup karyawan Pusat Penelitian Kopi dan Kakao. Serta mendapatkan bonus dan insentif lain yang diberikan saat akhir tahun dapat membantu meningkatkan perekonomian karyawan, dalam wawancara disebutkan pula aset yang dimiliki karyawan saat bekerja di Pusat Penelitian Kopi dan Kakao. Untuk karyawan laki-laki menyatakn bahwa pengaturan pengeluaran diatur oleh istri, sedangkan karyawan perempuan menyatakan bahwa dalam pengaturan pengeluaran lebih memilih untuk membuat anggaran rencana pengeluaran bulanan untuk mengantisipasi pengeluaran yang berlebihan, dan lebih memilih untuk mengikuti arisan untuk menyimpan vangnya.

Rata-rata dari karyawan telah memiliki rumah dan kendaraan baik itu mobil maupun motor secara pribadi. Serta persiapan masa depan saat masa pensiun, karyawan menyatakan bahwa telah mempersiapkan dari sekarang dengan memiliki aset yang berupa toko, bisnis pribadi, sawah, kos-kosan, ternak sapi/kambing dan asuransi pendidikan untuk anak.

\section{Agama}

Dalam wawancara 5 orang menyatakan jarang mengikuti pengajian rutin ini karena alasan hari Minggu adalah hari untuk melakukan acara lain, serta tempat pengajian yang jauh dari rumah, karena lokasi pengajian dengan tempat tinggal karyawan (mayoritas tinggal di kota Jember) jauh dari area kantor perkebunan Puslitkoka yang terletak di daerah perkebunan Desa Nogosari Kecamatan Rambipuji, dan pengajian di pusatkan di Masjid Baitul Muttaqin Puslitkoka. Sedangkan 4 orang karyawan menyatakan rutin mengikuti pengajian karena mereka tinggal di perumahan karyawan yang terletak di belakang area kantor Puslitkoka.

Jiwa

Seluruh karyawan Pusat Penelitian Kopi dan Kakao mulanya mendapatkan asuransi kesehatan penuh dari pihak manajemen Puslit. Namun setelah adanya program BPJS Kesehatan, program 
asuransi kesehatan dari Puslitkoka dialihkan pada BPJS Kesehatan. Sehingga karyawan diwajibkan untuk mengikuti program ini dan membayar iuran rutin setiap bulan berdasarkan kelas golongannya. Saat di wawancarai terkait indikator maqashid syariah khususnya pemenuhan dan perlindungan terhadap jiwa yaitu program asuransi kesehatan, Kepala Urusan Kepegawaian \& Pengembangan SDM Puslitkoka Bapak Ir. Sahali, MM menyatakan bahwa sebelum adanya program BPJS Kesehatan tagihan biaya kesehatan karyawan dan keluarganya ditanggung sepenuhnya oleh pihak Manajemen Puslitkoka. Namun sejak adanya program BPJS Kesehatan, pihak Manajemen hanya membayar separuhnya. Sehingga pihak manajemen dapat mengurangi tagihan biaya kesehatan dari rumah sakit yang menjadi rujukan Puslitkoka sebesar 50-75\%. Hal ini terjadi karena sebelum adanya BPJS Kesehatan karyawan seringkali datang ke dokter spesialis walaupun sakit yang diderita hanya sekedar sakit biasa dan tidak fatal, sehingga dengan fasilitas pembayaran kesehatan yang diberikan Puslitkoka secara penuh, biaya dari perlindungan kesehatan karyawan seringkali membengkak.

Akal

Pelatihan dan pengembangan merupakan usaha yang dilakukan untuk meningkatkan kompetensi peneliti dan karyawan Puslitkoka di lingkungan organisasi. Pelatihan dan pengembangan sangat berperan serta dalam peningkatan skill dan kemampuan intelektual. Kepala Urusan Kepegawaian dan Pengembangan SDM Bapak Ir. Sahali, MM menyatakan bahwa pada dasarnya pelatihan yang diberikan pada karyawan untuk meningkatkan keterampilan sesuai dengan bidang masing-masing karyawan. Ada juga pelatihan yang diikuti oleh karyawan namun tidak sesuai dengan bidang kerjanya, hal ini dilakukan untuk menambah skill lain diluar bidangnya. Misalnya saja karyawan bagian marketing yang mengikuti pelatihan agronomi dan kursus perpajakan.

\section{Keturunan}

Seluruh karyawan menyatakan bahwa di Pusat Penelitian Kopi dan Kakao terdapat cuti hamil dan haid yang diperuntukkan khususnya karyawan perempuan. Hal ini terkait dengan pengaturan mengenai cuti hamil yang diatur dalam Pasal 82 UU No. 13 Tahun 2003 tentang Ketenagakerjaan, pekerja perempuan berhak memperoleh cuti selama 1,5 bulan sebelum melahirkan dan 1,5 bulan sesudah melahirkan atau jika diakumulasi menjadi 3 bulan. Sedangkan cuti haid diberikan kurang lebih 4-5 hari, namun hampir tidak pernah ada karyawan perempuan yang menggunakan cuti haid.

Dahulu manajemen Pusat Penelitian Kopi dan Kakao bertanggungjawab penuh dalam memberikan jaminan fasilitas kepada karyawan yang tengah melahirkan, berupa fasilitas persalinan (baik normal ataupun caesar). Namun sejak adanya program BPJS segala urusan 
fasilitas kesehatan dan persalinan di limpahkan pada BPJS. Jadi apabila ada karyawan yang melahirkan secara caesar dan menggunakan fasilitas VIP (kelas atas) padahal BPJS yang dibayarkan adalah kelas di bawahnhya, makan penambahan biaya harus dibayar secara pribadi oleh karyawan yang bersangkutan.

Harta

Insentif merupakan pendapatan karyawan di luar gaji pokok yang diberikan oleh pihak manajemen Puslitkoka. Gaji diberikan pada karyawan di awal bulan sesuai dengan golongan dan jabatan yang dimiliki oleh karyawan. Insentif diberikan sebagai tambahan vang diluar gaji sebagai bentuk apresiasi pihak manajemen terhadap karyawan. Macammacam insentif ini antara lain seperti jasa produksi, tunjangan prestasi, honor menjadi narasumber seminar atau pelatihan, Tunjangan Hari Raya, Tunjangan Struktural dan hadiah.

\section{SIMPULAN}

Kesimpulan dari penelitian ini adalah pemenuhan kebutuhan kesejahteraan bagi karyawan Pusat Penelitian Kopi dan Kakao masih pada peringkat dharuriyyat. Hal ini dapat dilihat dari 5 aspek yang merupakan perspektif dalam penelitian ini.

Aspek agama, yaitu pemenuhan tempat sholat yang disediakan oleh Pusat Penelitian Kopi dan Kakao, yang seluruhnya suci, bersih dan wangi. Di tempat sholat terdapat tempat yang disediakan untuk berwudlu. Terdapat alat sholat bagi perempuan, dan alat sholat bagi laki-laki, sehingga kebutuhan hajiyyat sudah dapat terpenuhi. Waktu sholat disediakan bebas ketika disela-sela jam bekerja. Penyelenggaraan pengajian telah memenuhi kebutuhan dharuriyyat, hal ini dikarenakan tidak semua karyawan yang menghadiri pengajian majelis Ad Dhuha yang yang diselenggarakan khusus oleh pihak manajemen. Untuk pembayaran zakat dapat dibayarkan secara koletif melalu amil yang sudah ditunjuk oleh pihak manajemen.

Aspek jiwa mulanya dipenuhi dengan asuransi kesehatan penuh dari pihak manajemen Puslit. Namun setelah adanya program BPJS Kesehatan, program asuransi kesehatan dari Puslitkoka dialihkan pada BPJS Kesehatan. Fasilitas kesehatan lainnya yaitu adanya puskesmas keliling tiap 3 bulan sekali yang diadakan Puslitkoka bertempat di halaman belakang depan masjid. Puskesmas keliling ini melayani karyawan yang mempunyai keluhan keehatan, sehingga dapat memeriksakan kesehatannya di Puskesmas keliling tersebut. Sehingga pemenuhan sampai pada peringkat hajiyyat.

Dari aspek akal pengembangan karyawan berupa jenjang pendidikan karyawan khususnya peneliti, serta manajemen Pusat Penelitian Kopi dan Kakao berkewajiban memfasilitasi. Pemberian pelatihan bagi seluruh karyawan dilakukan rutin dan dianggarkan setiap tahunnya. Perlindungan akal bagi karyawan dipenuhi dengan pengembangan 
keilmuan dan pelatihan. Pelatihan yang diberikan pada karyawan untuk meningkatkan keterampilan sesuai dengan bidang masing-masing karyawan. Ada juga pelatihan yang diikuti oleh karyawan namun tidak sesuai dengan bidang kerjanya, hal ini dilakukan untuk menambah skill lain diluar bidangnya. Pemberian pelatihan di luar bidang keilmuan sering diadakan seperti workshop dan seminar, yang bisa di ikuti oleh seluruh karyawan Puslitkoka. Khusus untuk peneliti diwajibkan meneruskan jenjang yang lebih tinggi yaitu S2 dan S3. Sehingga untuk pengembangan Pusat Penelitian Kopi dan Kakao hanya sampai pada peringkat dharuriyyat,sedangkan pelatihan pada peringkat hajiyyat.

Aspek keturunan pemberian cuti bagi karyawan yang tengah hamil dan melahirkan serta cuti haid. Serta pemberian fasilitas persalinan. Cuti hamil dan melahirkan yakni tiga bulan. Sedangkan untuk cuti haid diberikan 4-5 hari, namun jarang karyawan yang mengambil cuti haid. Waktu tiga bulan ini terbagi 1 bulan sebelum melahirkan dan 2 bulan setelahnya. Sehingga pemenuhan kebutuhan aspek keturunan hanya sampai pada peringkat hajiyyat.

Aspek harta di Pusat Penelitian Kopi dan Kakao Indonesia dipenuhi dengan pemberian gaji pada karyawan secara tepat waktu, dan insentif lain seperti jasa produksi (jaspro), tunjangan prestasi, honor menjadi narasumber seminar atau pelatihan, Tunjangan Hari Raya,
Tunjangan Struktural dan hadiah yang diberikan kepadakaryawan. Sehingga, pemenuhan kesejahteraan dalam aspek harta hanya sampai pada peringkat hajiyyat.

\section{DAFTAR PUSTAKA}

Afifuddin dan Beni Ahmad Saebani. 2009. Metodologi Penelitian Kualitatif. Bandung: Pustaka Setia.

Al-Qur'an Tafsir dan Terjemahannya. 1978. Bandung: Firma Sumatra Bandung

Anshori, Muslich \& Sri Iswati. 2009. Buku Ajar Metodologi Penelitian Kuantitatif. Cetakan pertama. Surabaya: Airlangga University Press.

Asyafri. 1996. Konsep Maqashid Syari'ah menurut Syaitibi, Jakarta: Raja Grafindo Persada.

Bungin, Burhan. 2008. Penelitian Kualitatif. Jakarta:Kencana.

Bakri, Asafri Jaya. 1994. Konsep Maqashid Syari'ah menurut al-Syatibi. Jakarta: Rajawali Press.

Cresswell. 1998. Research Design (Pendekatan Kualitatif, Kuantitatif, Mixed). Jakarta:Pustaka Pelajar.

Departemen Pendidikan dan Kebudayaan. 1998. Kamus Besar Bahasa Indonesia. Jakarta: Balai Pustaka

Duhriah. 2015. Tingkatan-Tingkatan Maqashid Al-Syariah: al-Dharruruyyat, al-Hajiyyat, dan al-Tahsiniyyat. Jurnal Vol. 01 No. 1 Januari-Juni 2015 hal 191210 .

Handoko, T. Hani, 2000. Manajemen Sumber Daya Manusia. Yogyakarta: BPFE. 
Hasibuan, Malayu. 2003. Manajemen

Sumber Daya Manusia, Edisi Revisi. Jakarta: Bumi Aksara.

Husein, Umar. 1999. Riset Sumber Daya Manusia Dalam Organisasi. Edisi revisi, Jakarta: Gramedia.

Karim, Adiwarman A. 2010. Ekonomi Mikro Is/ami. Edisi Ketiga. Jakarta: Raja Grafindo Persada

Latief. 2012. Faktor-Faktor yang Mempengaruhi Kinerja Karyawan PT Mega Mulia Servindo Makassar. 2012. Makassar:Universitas Hasannudin

Lembaga Penerjemah dan Tafsir AlQur'anAI-Quran dan Terjemahannya. Mangkunegara, AA. Anwar Prabu. 2000. Manajemen Sumber Daya Manusia Perusahaan. Bandung: Rosada .

Miyagi, Khea. 2014. Perbandingan Kesejahteraan antara Pengusaha dan Pegawai Prespektif Maqashid Syariah di Kelurahan Kejawan Putih Tambak Surabaya. Skripsi tidak diterbitkan program sarjana Universitas Airlangga Surabaya.

Moleong, Lexy J. 2000. Metode Penelitian Kualitatif. Bandung: PT.Remaja Rosdakarya.

Mursi, Abdul Hamid. 1997. Sumber Daya Manusia yang Produktif Pendekatan AlQur'an dan Sains. Jakarta: Gema Insani Press.

Nawawi, Hadari. 2005. Metode Penelitian Bidang Sosial. Yogyakarta: Gajah Mada Press.

2001. Kepemimpinan Menurut Islam. Yogyakarta: Gadjah Mada University Press.
Nazir, Muhammad. 2003. Metode Penelitian. Jakarta: Ghalia Indonesia.

Pusat Pengkajian dan Pengembangan Ekonomi Islam (P3EI), 2008, Ekonomi Islam. Jakarta: PT. Rajagrafindo Persada.

Qordhawi, Yusuf. 2000. Pesan Nilai dan Moral Dalam Perekonomian Islam. Jakarta: Robbani Press.

Rivai, Veithzal. 2009. Manajemen Sumber Daya Insani. Jakarta: Rajawali Pers.

Shihab, Quraish. 2002. Tafsir Al Misbah Pesan Kesan dan Keserasian Al-Qur'an. Jakarta: Lentera.

Sjahrir. 1988. Kebijakan Negara : Konsistensi dan Implementasi. Jakarta: LP3ES. Siswanto. 2006. Pengantar Management. Jakarta: Bumi aksara.

Spradley. 1997. Metode Etnografi. Jakarta:Tiara Wacana. $\mathrm{H}$

Sugiyono. 2013. Memahami Penelitian Kualitatif. Bandung: Alfabeta

Sumadi Suryabrata. 1994. Metodologi Penelitian. Jakarta: Rajawali

Universitas Airlangga Fakultas Ekonomi. 2009. Pedoman Penulisan, Pembimbingan \& Ujian Skripsi. Surabaya: Airlangga UniversityPress.

Wibowo, Arif. 2012. Maqoshid Asy Syariah: The Ultimate Objective of Syariah. Islamic Finance.

Widiastuti, Tika. 2008. Dampak korupsi terhadap tingkat kesejahteraan masyarakat di beberapa negara muslim. Tesis tidak diterbitkan. Program Pasca Sarjana Universitas Indonesia. 
Yin. 2002. Studi Kasus Desain dan Metode.Jakarta: PT Raja Grafndo Persada.

Yin. 2009. Studi Kasus Desain Metode. Jakarta: PT. Grafindo Persada.

Yukl, Gary. 2005. Kepemimpinan dalam Organisasi. Edisi kelima. Terjemahan. Jakarta: PT.Indeks Kelompok GRAMEDIA.

Zuhaili, Wahbah. 2010. Fiqih Imam Syafi'i. Jakarta: PT Niaga Swadaya.

Sumber Lain:

Undang-Undang No.13 tahun 1998 pasal 1 tentang Kesejahteraan www.Karakteristikmasyarakat.Co.id diakses pada tanggal 5 Maret 2016 http://www.kompasiana.com/saifulrobba ni/konsep-islam-tentang-perubahansosial_550d6e43a333118b1b2e3b27 di akses pada tanggal 29 Februari 2016 https://mlatief.wordpress.com/2008/03/11/ perubahan-sosial-dalam-perspektif-alqur\%E2\%80\%99an/ di akses pada tanggal 29 Februari 2016. 